\title{
Inoculation expérimentale de l'agent de la péripneumonie contagieuse bovine à des chèvres
}

\author{
A. Yaya ${ }^{1}$ B. Hamadou ${ }^{1}$ D. Yaya ${ }^{1}$ S. Abdoulkadiri ${ }^{1}$ \\ F. Thiaucourt ${ }^{2}$
}

\section{Mots-clés}

Caprin - Péripneumonie contagieuse bovine - Infection expérimentale - Test Elisa.

\begin{abstract}
Résumé
L'expérience réalisée a eu pour but de vérifier la réceptivité des chèvres à l'agent de la péripneumonie contagieuse bovine. Q uatre voies d'inoculation ont été expérimentées : les voies sous-cutanée, endobronchique, intrapleurale et intrapéritonéale. Une des chèvres inoculées par la voie intrapéritonéale a succombé à une péritonite et l'agent de la péripneumonie a pu être isolé à nouveau du liquide ascitique présent. Les sérologies effectuées ont permis de mettre en évidence des séroconversions chez un certain nombre d'animaux, notamment par la technique d'Elisa de compétition. Ce résultat ouvre la voie à des enquêtes de terrain pour déterminer si des chèvres en contact avec des bovins atteints de la péripneumonie peuvent être naturellement contaminées.
\end{abstract}

\section{INTRO DUCTION}

La péripneumonie contagieuse bovine (ppcb) est une maladie infectieuse, due à un mycoplasme, Mycoplasma mycoides subsp. mycoides petite colonie (MmmSC). Comme son nom l'indique, cette infection ne touche, naturellement, que le genre Bos, c'est-àdire les bovins (taurins et zébus) (14) chez lesquels elle se caractérise principalement par des lésions de pleurésie et de pneumonie. De la même manière, la pleuropneumonie contagieuse caprine, due à $M$. capricolum subsp. capripneumoniae (Mccp), ne touche que les caprins. Cependant la stricte spécificité d'espèce et de localisation de certains mycoplasmes a été remise partiellement en cause. C'est ainsi que Mccp a pu être isolé chez des moutons $(3,10)$ sans que l'on puisse établir précisément si cet agent était responsable d'une affection quelconque. Chez les bovins, bien que les lésions caractéristiques de la ppcb se situent dans l'arbre respiratoire, il est possible d'isoler l'agent responsable (MmmSC) d'autres organes. Des isolements ou des identifications ont ainsi été réalisés à partir de sperme ou de lavage préputial de taureau $(7,15)$. De même, des souches de MmmSC ont été isolées chez des chèvres au Soudan, au Nigeria (13) et, plus récemment, au Portugal, sans que ces souches puissent être différentiées de celles affectant les bovins (7). Certaines de ces souches avaient été isolées avant que la distinction entre les biotypes « small colony » et « large colony » ait été faite, mais des études récentes impliquant des tests par amplifi-

\footnotetext{
1. Lanavet, BP 503, Garoua, Cameroun

2. Cirad-emvt, TA30/G, Campus international de Baillarguet, 34398 Montpellier Cedex 5, France
}

cation en chaîne par polymérase (pcr) spécifiques ont bien confirmé l'identification de ces souches d'origine caprine, notamment la souche «Vom » venant du Nigeria (5)

La question de la réceptivité d'autres espèces que les bovins a déjà été étudiée par plusieurs auteurs notamment à travers des infections expérimentales. Cependant il semble que des résultats contradictoires aient été obtenus. Curasson (4) note qu'il est important de bien distinguer les pleuropneumonies qui peuvent se rencontrer chez les petits ruminants de la ppcb. Bien qu'il n'ait pas lui-même réussi à provoquer la moindre lésion chez les moutons, il cite un certain nombre d'auteurs qui y sont parvenus. Avant l'isolement de l'agent de la ppcb (11) les expérimentations se faisaient à partir de liquide pleural récolté chez des bovins. Dans ces conditions, par exemple, Galtier a reproduit la maladie chez des chèvres en leur faisant ingérer du poumon de bovin atteint de ppcb. Après le succès rencontré dans l'isolement de l'agent responsable, les inoculations ont pu être faites à partir de culture pure. Cependant, il semble que le type de sérum utilisé pour la culture ait une influence sur le résultat final (6), un phénomène de Willems n'étant obtenu chez la chèvre et le mouton que lorsque l'agent de la ppcb a, au préalable, été cultivé sur du sérum homologue. Beller et Thassin-Bey ont également réussi à reproduire la maladie chez le mouton (2) ainsi que Turner et coll. en Australie (16).

Il semble que très peu de reproductions expérimentales aient été effectuées par la suite chez les petits ruminants (8), sans doute parce que les moutons et les chèvres ne jouent un rôle que très marginal, sinon inexistant, dans la transmission naturelle de la maladie dans des pays où elle sévit sous forme d'épizooties ou 
d'enzooties. Dans d'autres circonstances, en particulier dans des pays où l'éradication a été obtenue récemment, un portage inapparent chez d'autres espèces que l'espèce bovine pourrait avoir des conséquences dramatiques. L'isolement de MmmSC chez des chèvres dans une zone du Portugal où aucun foyer de ppcb n'avait été déclaré (Regalla, commun. pers.) soulève des inquiétudes et a conduit les auteurs à entreprendre de nouvelles expérimentations chez les chèvres.

L'objectif de l'étude a été de vérifier la réceptivité de cette espèce à des injections réalisées par différentes voies avec une souche dont le pouvoir pathogène avait bien été établi chez les bovins (17).

\section{- MATERIEL ET METHODES}

\section{Animaux}

Trente chèvres ont été prises au hasard parmi 87 animaux disponibles. Elles ont ensuite été réparties de manière aléatoire parmi les cinq groupes définis par le protocole expérimental. Elles ont été maintenues en claustration dans un enclos avec de l'eau ad libitum et une ration de fourrage complémentée de fanes de haricots et de tourteaux de coton. Elles ont reçu un traitement contre les parasites gastro-intestinaux 15 jours avant l'inoculation.

\section{Protocole expérimental}

Quatre voies d'inoculation ont été retenues : les voies transtrachéale, sous-cutanée, intrapéritonéale et intrapleurale. L'injection transtrachéale a été réalisée chez huit chèvres avec $15 \mathrm{ml}$ de culture de la souche 8740 additionnés de $5 \mathrm{ml}$ d'agar noble (Difco) à 1,5 p. 100. Cinq millilitres de milieu stérile HIB (Difco) ont ensuite été injectés pour effectuer un rinçage de la seringue. Quatre animaux témoins ont été inoculés de la même manière en remplaçant la culture par du milieu HIB stérile. L'injection sous-cutanée a été réalisée avec $2 \mathrm{ml}$ en arrière de l'épaule chez quatre animaux. Deux animaux témoins ont été inoculés de la même manière avec du milieu stérile. L'injection intrapéritonéale a été réalisée avec $2 \mathrm{ml}$ de culture, en arrière de l'ombilic sur la ligne blanche, chez quatre animaux. Deux animaux témoins ont été inoculés de la même manière avec du milieu stérile. Enfin, l'injection intrapleurale a été effectuée par injection de $2 \mathrm{ml}$ de culture dans un espace intercostal chez quatre animaux. Deux animaux témoins ont été inoculés de la même manière avec du milieu stérile.

\section{Suivi clinique}

La température rectale des animaux a été mesurée régulièrement trois fois par semaine, le matin avant $10 \mathrm{~h}$, pendant les deux mois de l'expérimentation. Des prises de température ont également été réalisées pendant deux semaines avant l'inoculation afin d'habituer les animaux. L'augmentation de la température induite par les différents modes d'inoculation a été évaluée en calculant, pour chaque animal, la différence entre les températures mesurées un jour et 4 jours après l'inoculation et celles mesurées un jour, 5 jours et 7 jours avant l'inoculation. Les réactions au point d'inoculation ont été relevées par palpation durant les trois premières semaines et les signes généraux éventuels ont été observés régulièrement tout au long de l'expérimentation.

\section{Suivi sérologique}

Des prises de sang ont été effectuées toutes les semaines, la première ayant eu lieu une semaine avant l'inoculation. Les sérums ont ensuite été analysés par Elisa indirect ou cElisa (9).

\section{Bactériologie}

A l'autopsie, deux mois après l'inoculation chez les animaux ayant survécu, les mycoplasmes ont été recherchés par culture sur milieu solide et liquide, à partir d'échantillons prélevés au point d'inoculation et du nœud lymphatique régional. L'identification des souches de MmmSC a été réalisée par inhibition de croissance et pcr avec les amorces décrites par Bashiruddin et coll. (1) et Dedieu et coll. (5).

\section{RESU LTATS ET DISCUSSIO N}

\section{Températures}

La température moyenne «normale », mesurée avant les inoculations sur l'ensemble du troupeau sur deux jours, s'est élevée à $37,7{ }^{\circ} \mathrm{C}$ (écart-type $=0,8 ; \mathrm{N}=60$ ). Aucune augmentation significative de la température n'a été observée sur les animaux contrôles quel qu'ait été le mode d'inoculation. L'inoculation d'une culture virulente, au contraire, a induit une augmentation significative de la température (figure 1) qui a varié de $0,5{ }^{\circ} \mathrm{C}$ pour la voie intrapleurale à $1,9{ }^{\circ} \mathrm{C}$ pour la voie transtrachéale. Les voies sous-cutanée et intrapleurale ont induit, quant à elles, des augmentations de l'ordre de $1{ }^{\circ} \mathrm{C}$. Lorsque la fièvre a été présente chez un animal, elle a persisté en général pendant huit jours.

Dans les conditions expérimentales de l'étude, c'est la voie transtrachéale qui a induit l'augmentation de température la plus importante. Cette augmentation peut s'expliquer par le volume de culture plus important (15 $\mathrm{ml}$ au lieu de $2 \mathrm{ml})$, ainsi que par l'action éventuellement adjuvante de l'agar incorporé dans l'inoculum.

L'animal qui a succombé à une péritonite a présenté une courbe de température exemplaire (figure 2). Après une hyperthermie transitoire, sans doute due au stress de manipulation auquel l'animal n'était pas habitué, la température s'est stabilisée à une valeur normale $\left(36,5-37,5^{\circ} \mathrm{C}\right)$ et l'inoculation a été suivie d'une augmentation rapide de la température avec un maximum à $39,6^{\circ} \mathrm{C}$. La mort a été précédée d'une hypothermie.

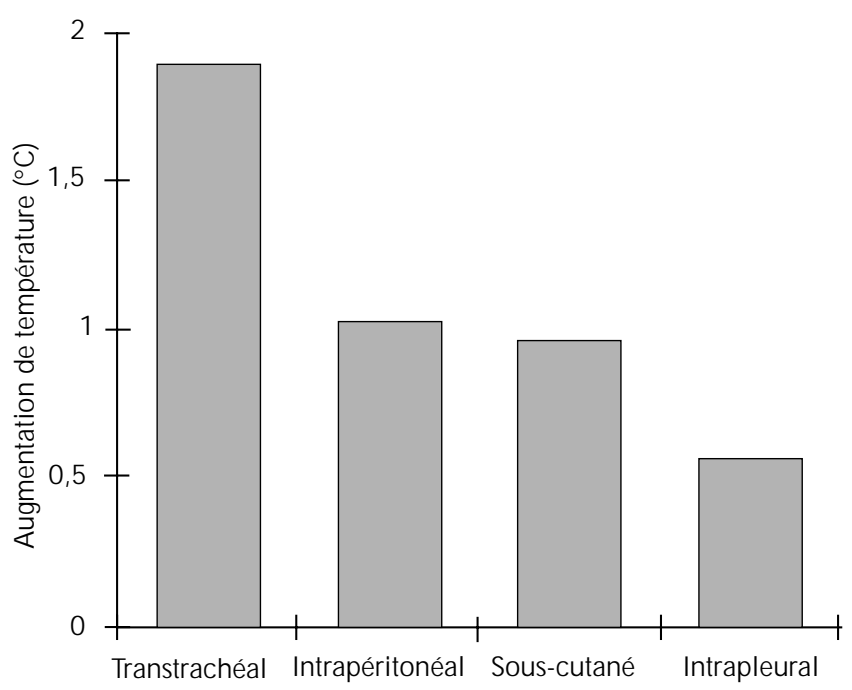

Figure 1 : augmentations moyennes des températures rectales induites par les différentes inoculations. Les différences ont été calculées à partir des mesures effectuées la semaine précédant l'inoculation et celles effectuées le lendemain puis quatre jours après l'inoculation. 


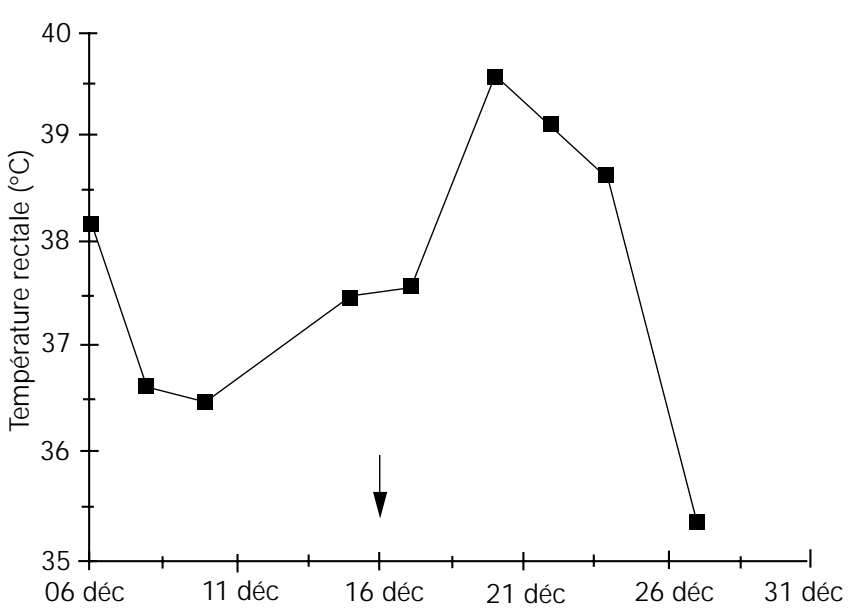

Figure 2 : courbe de température de l'animal ayant présenté une péritonite. La flèche indique la date d'inoculation.

\section{Observations cliniques}

Seuls deux animaux ont succombé au cours de cette expérimentation ; tous deux provenaient du lot inoculé par la voie intrapéritonéale. L'animal $n^{\circ} 58$ est mort 12 jours après l'inoculation et il a présenté à l'autopsie des signes de péritonite avec du liquide d'ascite. L'animal n 613 est mort plus de trois mois après l'inoculation et il a présenté à l'autopsie des signes d'hépatisation d'une couleur rouge brique uniforme sur le lobe pulmonaire apical droit et la présence de liquide pleural des deux côtés du poumon. Des réactions inflammatoires locales ont été notées chez quelques animaux mais ces réactions ont toujours été circonscrites et transitoires. Elles n'ont jamais évolué en phénomène de Willems.

\section{Observations bactériologiques}

Le titre initial de la culture inoculée aux différents animaux était de $10^{9,1}$ par millilitre. Une culture pure de MmmSC a été isolée du liquide d'ascite de l'animal $n^{\circ} 58$. L'identification a été réalisée à la fois par inhibition de croissance avec du sérum hyperimmun anti-PG1 et par pcr. Le titre de ce liquide d'ascite était de $10^{9,2}$ par millilitre ce qui indique bien une multiplication de la souche inoculée. En revanche, aucune culture de mycoplasme ni aucune détection par pcr n'ont pu être obtenues à partir du liquide pleural de l'animal $n^{\circ} 613$.

\section{Observations sérologiques}

\section{Témoins}

Dans les conditions de réalisation des réactions, les densités optiques (DO) obtenues en Elisa indirect pour les animaux contrôles se sont toutes situées entre 0 et 1,2, à l'exception de l'animal $n^{\circ} 22$ pour lequel il a semblé exister une séroconversion (figure 3a). Les titres obtenus en Elisa de compétition ont tous été inférieurs à 40 p. 100, y compris pour l'animal n 22 (figure $3 b$ ). Pour ce dernier animal il y a donc eu une discordance entre les deux tests et il importerait de pouvoir vérifier si la séroconversion a bien été spécifiquement dirigée contre MmmSC.

\section{Voie transtrachéale}

Les séroconversions obtenues dans ce groupe ont été les plus fortes, en Elisa indirect comme en Elisa de compétition (figures $3 \mathrm{~b}$ et $3 \mathrm{c}$ ). Il y a cependant eu une certaine variabilité d'un animal à l'autre, certains animaux ayant fait une séroconversion précoce élevée et durable (animal $n^{\circ} 772$ ), alors que d'autres ont fait des séroconversions plus transitoires (animal $n^{\circ} 21$ ). Comme pour l'élévation de la température, les séroconversions les plus fortes dans ce groupe pouvaient avoir été corrélées à la voie utilisée, à un volume d'inoculum plus important, aussi bien qu'à l'adjonction d'agar qui a pu jouer un rôle d'adjuvant.

\section{Voies sous-cutanée, intrapleurale et intrapéritonéale}

Dans ces trois groupes, deux types d'individus ont pu être identifiés. Certains ont présenté une séroconversion, les autres non (figures $3 \mathrm{e}$ à $3 \mathrm{j}$ ).

\section{- CONCLUSION}

Cette expérimentation a permis de confirmer que les chèvres ne sont pas extrêmement réceptives à l'agent de la ppcb et que, dans les conditions de l'étude, il n'a pas été observé de phénomène de Willems au point d'injection. La réceptivité des chèvres n'a pas cependant été nulle. En effet un des animaux, inoculé par la voie intrapéritonéale, a succombé à une péritonite, avec isolement ultérieur de MmmSC. Bien qu'un seul animal ait succombé ou présenté des symptômes sur les 20 inoculés, il faut mettre en parallèle ce résultat avec les difficultés énormes qui sont rencontrées chez l'espèce bovine pour reproduire la maladie chez des animaux intubés.

Apparemment l'inoculation par la voie transtrachéale n'a pas permis d'induire la moindre lésion pulmonaire ni aucune persistance de mycoplasme dans les nœuds lymphatiques régionaux. Il peut s'agir d'une moindre réceptivité effective des caprins ou bien encore d'un biais induit par le procédé d'inoculation qui n'a pas permis le dépôt de l'inoculum assez profondément dans l'arbre respiratoire. Dans les expériences réalisées à Garoua chez les bovins, un bronchoscope permettait en effet de déposer l'inoculum relativement profondément dans les bronches.

Aucun animal témoin n'a semblé être infecté. Cela n'est pas surprenant car aucun animal inoculé n'a présenté de symptôme respiratoire susceptible d'être à l'origine d'une contamination du milieu extérieur par la formation d'aérosol infectieux lors de toux. Le seul animal contaminé a présenté une péritonite, ce qui ne le rendait pas a priori infectant.

Un des objectifs de cette expérience a été de vérifier s'il était possible d'utiliser des chèvres à la place de bovins lors d'essais vaccinaux ultérieurs. L'utilisation de chèvres aurait pu, en effet, représenter un compromis acceptable entre les bovins, animaux de choix mais au prix de revient élevé, et les souris qu'il serait inutile de choisir étant donné leur système immunitaire très différent de celui des bovins. L'induction d'une péritonite chez une chèvre a montré qu'il était possible d'induire un phénomène pathologique chez cette espèce, ouvrant la voie à de futurs essais. Le manque de reproductibilité des résultats chez tous les animaux inoculés par la même voie ne permettent pas, pour le moment, de considérer les chèvres comme de bons modèles.

L'induction d'une péritonite chez une chèvre entraîne également de nouvelles perspectives de recherche chez les bovins, où il s'agirait de déterminer, en particulier, si la même voie d'inoculation peut induire des péritonites chez ces derniers. Ce type d'essai a d'ailleurs déjà été réalisé avec succès dans le passé par le découvreur de l'agent responsable de la péripneumonie (12). Cela permettrait éventuellement d'obtenir un système expérimental plus proche de la maladie naturelle que l'inoculation par la voie souscutanée et plus reproductible qu'une inoculation par la voie endobronchique et par la transmission par contact. L'utilité de certains adjuvants, destinés à exacerber le pouvoir pathogène des souches, pourrait être étudiée. 

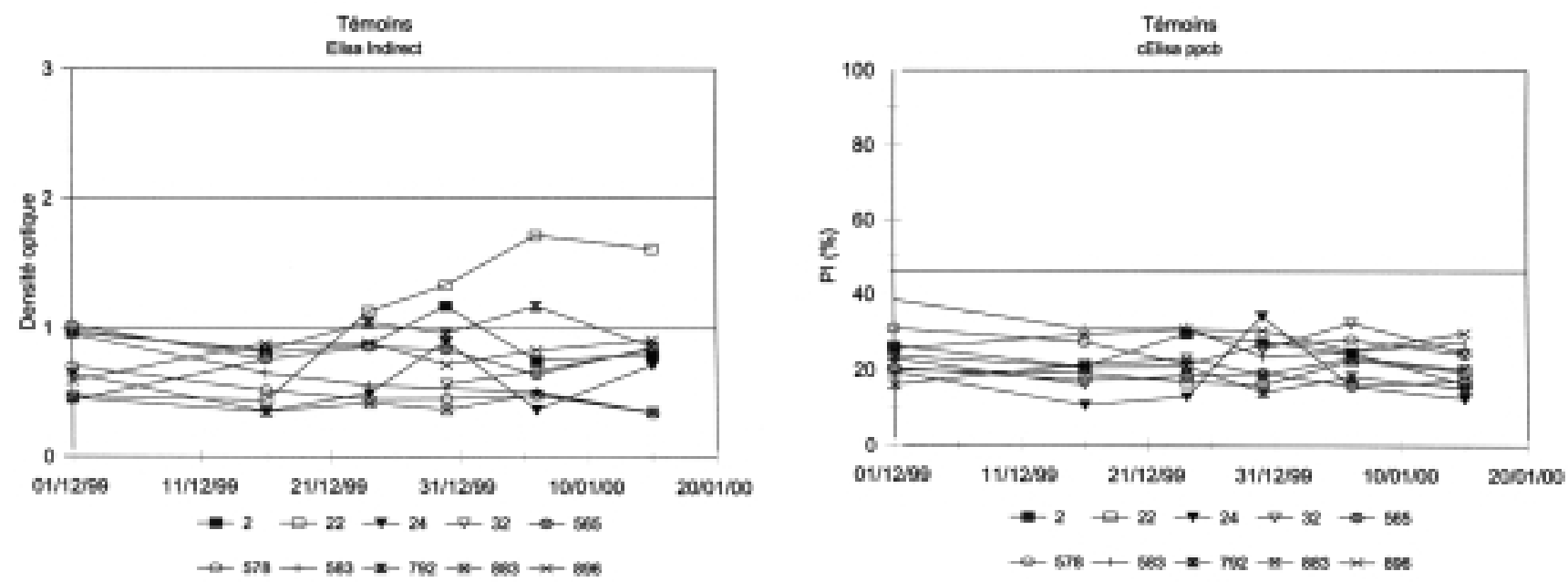

a

b
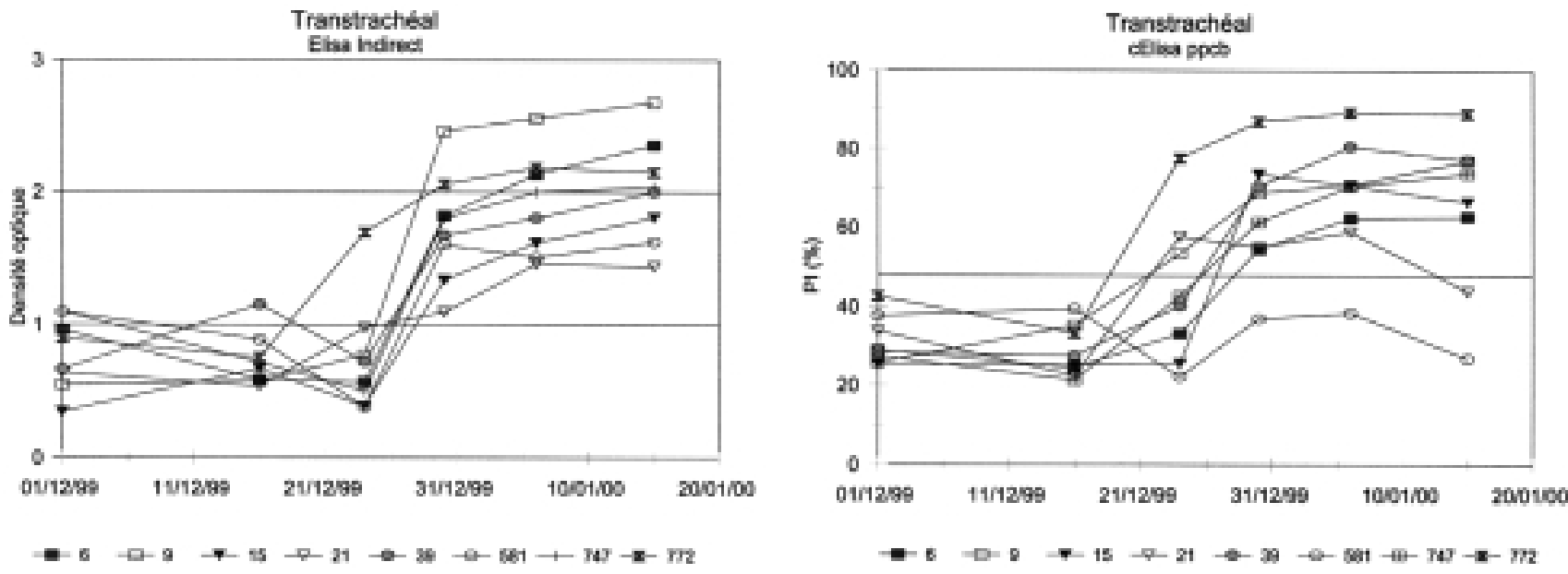

c

d
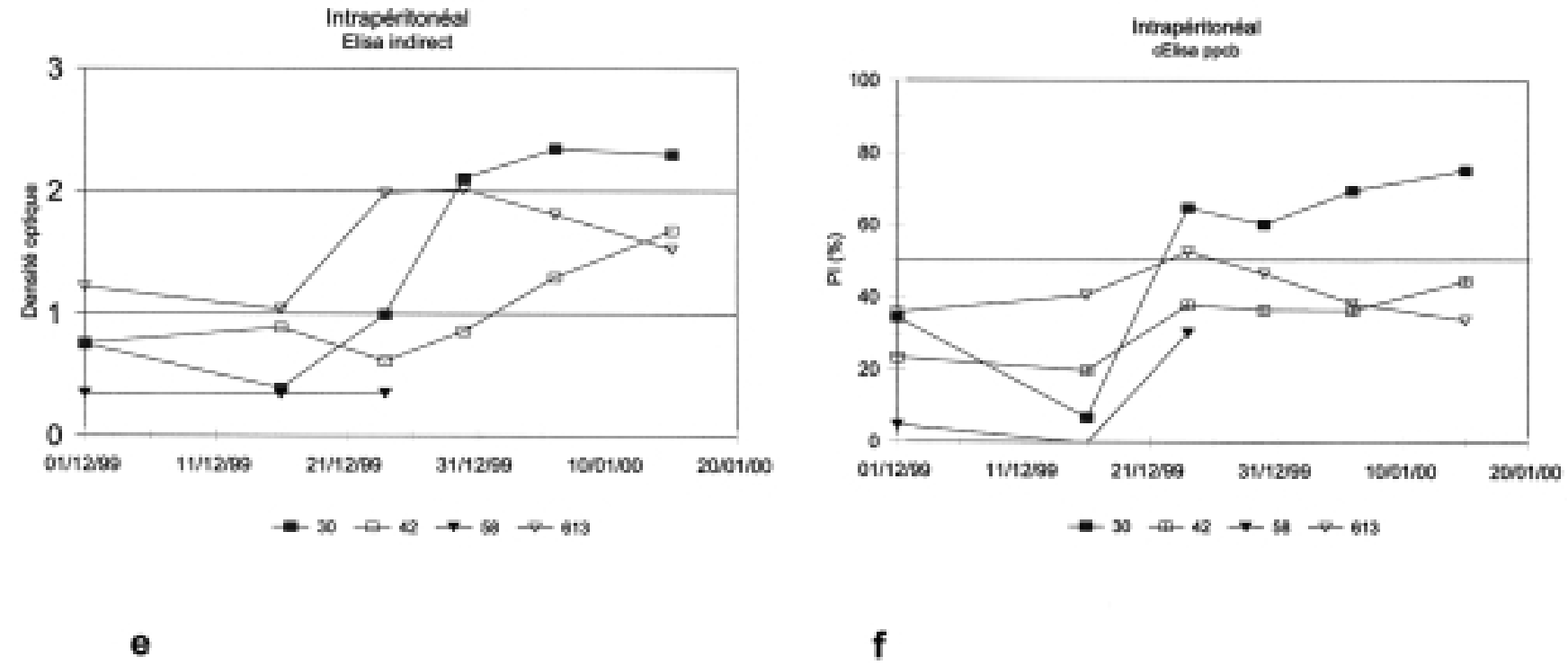

Figure 3 : cinétiques sérologiques mesurées par Elisa indirect $(a, c, e, g, i)$ ou Elisa de compétition (b, d, f, h, j) dans les différents groupes. 


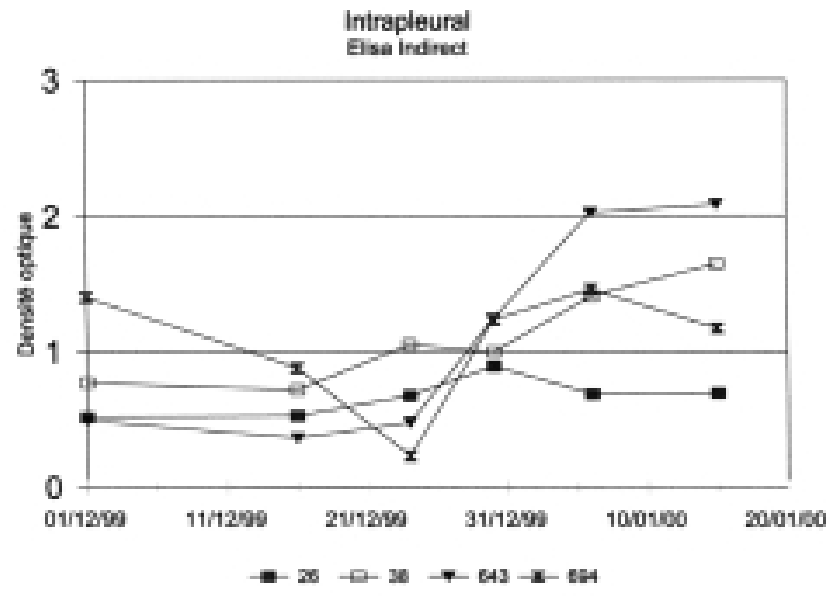

g

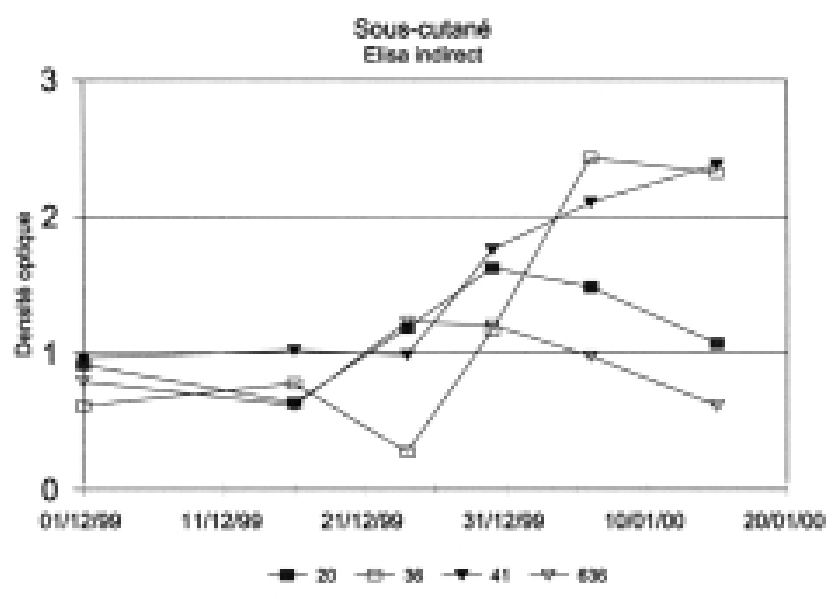

i

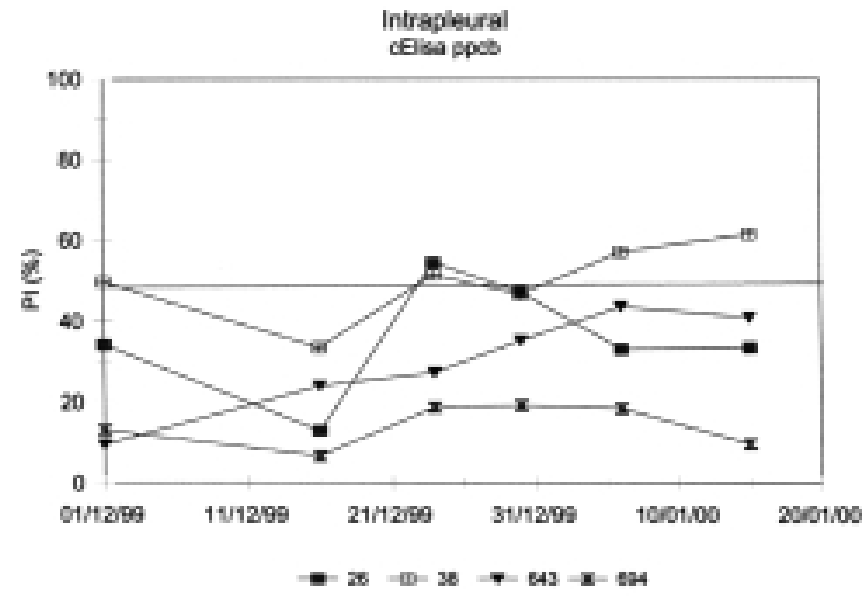

h

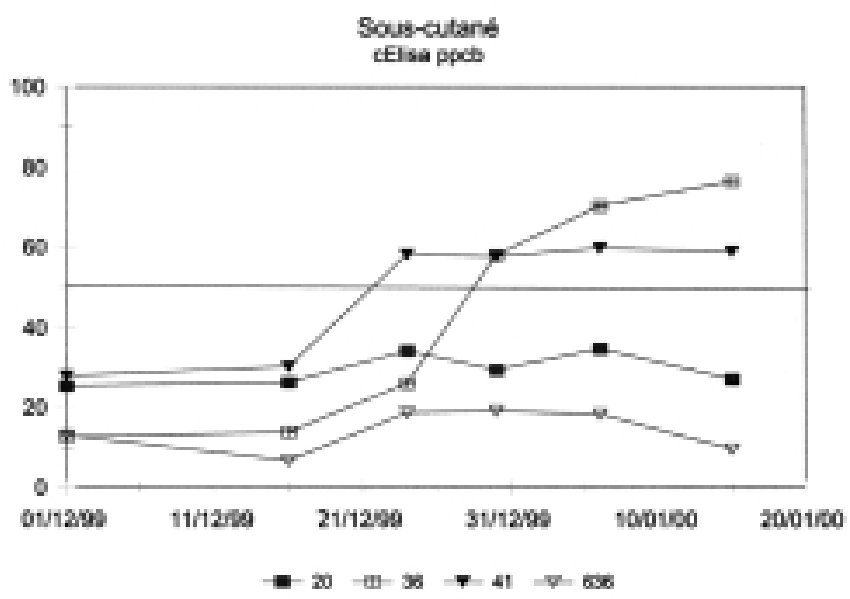

j

Figure 3 (suite) : cinétiques sérologiques mesurées par Elisa indirect $(a, c, e, g, i)$ ou Elisa de compétition (b, d, f, h, j) dans les différents groupes.

Les variations individuelles observées dans chaque lot au niveau des courbes de séroconversion semblent indiquer qu'il existe, à l'instar de ce qui se passe chez les bovins, une certaine variation de réceptivité liée aux individus. Il est donc tentant de vouloir étendre la recherche de marqueur de résistance ou de réceptivité à cette espèce. Cette recherche ne pourra cependant se réaliser qu'une fois les conditions de reproduction expérimentale mieux maîtrisées.

Cet essai a également permis de valider l'Elisa de compétition ppcb sur des sérums caprins. Les titres obtenus chez les animaux avant l'inoculation ont été tout à fait comparables aux titres obtenus chez des bovins n'ayant jamais eu de contact avec MmmSC, ce qui tend à montrer que le seuil de 50 p. 100 est également valable chez les chèvres. Ce même Elisa de compétition a permis de détecter une séroconversion notable chez un certain nombre d'animaux inoculés. Ici encore ce résultat montre l'intérêt de l'Elisa de compétition pour réaliser des enquêtes dans les troupeaux de chèvres qui sont en contact direct avec des foyers de péripneumonie chez des bovins. La mise en évidence de séropositivité chez certaines chèvres serait une preuve de la transmission interespèces qui mériterait alors d'être évaluée bien plus en détail.

\section{Remerciements}

Les auteurs tiennent à remercier tout particulièrement le Dr Provost de leur avoir fait profiter de ses conseils éclairés et de ses précieuses références bibliographiques. La réalisation de cette expérimentation au Lanavet a été rendue possible grâce à un financement du ministère français des Affaires étrangères, projet Ravira.

\section{BIBLIO GRAPHIE}

1. BASHIRUDDIN J.B., TAYLOR T.K., GOULD A.R., 1994. A PCR-based test for the specific identification of Mycoplasma mycoides subspecies mycoides SC. J. vet. Diagn. Invest., 6: 428-434.

2. BELLER K., TAHSSIN-BEY S., 1927. Neue Untersuchungen über Lungenseuche. Dtsch. Tierärztl. Wochenschr., 6: 90-95.

3. BO LSKE G., WILHELMSSO N E., TWINAMASIKO E., JOHANSSO N K.E., 1994. Detection of Mycoplasma capricolum subsp. capripneumoniae in goats and sheep in U ganda. IO M Lett., 3: 19-20.

4. CURASSON G., 1942. Péripneumonie bovine. In : Traité de pathologie exotique vétérinaire et comparée, vol. $2,2^{\mathrm{e}}$ ed. Paris, France, Vigot Frères, p. 276-353 
5. DEDIEU L., MADY V., LEFEVRE P.C., 1994. Development of a selective polymerase chain reaction assay for the detection of Mycoplasma mycoides subsp. mycoides SC (contagious bovine pleuropneumonia agent). Vet. Microbiol., 42: 327-339.

6. DUJARDIN-BEAUMETZ E., 1906. Transmission de la péripneumonie des bovidés aux espèces ovine et caprine. Ann. Inst. Pasteur, 20 : 449-466.

7. GONCALVES R., 1994. Isolation and identification of Mycoplasma mycoides subsp. mycoides SC from bull semen and sheath washings in Portugal. Vet. Rec., 135: 308-309.

8. GOURLAY R.N., 1964. Artificial reproduction of contagious bovine pleuropneumonia. Bull. epizoot. Dis. Afr., 12: 229-235.

9. LE GOFF C., THIAU COURT F., 1998. A competitive ELISA for the specific diagnosis of contagious bovine pleuropneumonia (CBPP). Vet. Microbiol., 60: 179-191.

10. LITAMOI J.K., WANYANGU S.W., SIMAN P.K., 1990. Isolation of Mycoplasma biotype F38 from sheep in Kenya. Trop. Anim. Health Prod., 22: 260-262.

11. NO CARD E., RO UX E., 1898. Le microbe de la péripneumonie. Ann. Inst. Pasteur, $12: 240-262$.

\section{Summary}

Yaya A., Hamadou B., Yaya D., Abdoulkadiri S., Thiaucourt F. Experimental Inoculation of Goats with the Contagious Bovine Pleuropneumonia Agent

The objective of the trial was to determine the susceptibility of goats to the contagious bovine pleuropneumonia (CBPP) agent. Four inoculation routes - subcutaneous, endobronchial, intrapleural and intraperitoneal - were tested. O ne of the goats infected intraperitoneally died of peritonitis. The CBPP agent was isolated again from the ascitic fluid. The serological tests, competition ELISA in particular, revealed the occurrence of serological conversions in a number of animals. This should pave the way to further field studies to determine if goats in contact with CBPP-affected bovines may be naturally contaminated.

Key words: Goat - Contagious bovine pleuropneumonia Experimental infection - ELISA.
12. NOCARD E., ROUX E., DUJARDIN-BEAUM MTZ E., 1899. Etudes sur la péripneumonie (deuxième note). Bull. Soc. cent., $17:$ 430-446.

13. PERREAU P., 1971. Identification de certaines souches de mycoplasmes de la chèvre à l'espèce Mycoplasma mycoides var mycoides. Revue Elev. Méd. vét. Pays trop., 24 : 343-348.

14. PROVOST A., PERREAU P., BREARD A., LE GOFF C., MARTEL J.L., COTTEW G.S., 1987. Péripneumonie contagieuse bovine. Revue sci. tech. O ff. int. Epizoot., 6 : 565-624.

15. STRADAIOLI G., SYLLA L., MAZZARELLI F., ZELLI R., RAWADI G., MONACl M., 1999. Mycoplasma mycoides subsp. mycoides SC identification by PCR in sperm of seminal vesiculitis affected bulls. Vet. Res., 30: 457-466.

16. TURNER A.W., CAM PBELL A.D., DICK A.T., 1935. Recent work on pleuro-pneumonia contagiosa boum (sic) (Bovum) in North Q ueensland. Aust. vet. J., 11: 63-71.

17. YAYA A., GOLSIA R., HAMADOU B., AMARO A., THIAUCOURT F., 1999. Essai comparatif d'efficacité de deux souches vaccinales T1/44 et T1sr contre la péripneumonie contagieuse bovine. Revue Elev. Méd. vét. Pays trop., $52:$ 171-179.

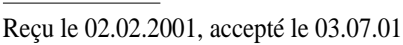

\section{Resumen}

Yaya A., Hamadou B., Yaya D., Abdoulkadiri S., Thiaucourt F. Inoculación experimental del agente de la perineumonía contagiosa bovina en cabras

El objetivo del experimento realizado fue el de verificar la receptividad de las cabras al agente de la perineumonía contagiosa bovina. Se experimentaron cuatro vías de inoculación: vía sub cutánea, endobronquial, intrapleural e intraperitoneal. Una de las cabras inoculadas vía intraperitoneal sucumbió con una peritonitis, siendo aislado nuevamente el agente de la perineumonía en el líquido de ascitis presente. Las serologías efectuadas permitieron demostrar las conversiones serológicas en algunos de los animales, principalmente mediante la técnica ELISA de competencia. El resultado abre la vía a estudios de campo para determinar si las cabras en contacto con bovinos enfermos de perineumonía podrían ser contaminadas de forma natural.

Palabras clave: Caprino - Pleuropneumonía contagiosa bovina - Infección experimental - ELISA. 